\title{
A TYPOLOGY OF COST ACCOUNTING PRACTICES BASED ON ACTIVITY-BASED COSTING - A STRATEGIC COST MANAGEMENT APPROACH
}

\author{
Gregory Wegmann \\ University of Burgundy, France \\ E-mail: gregory.wegmann@u-bourgogne.fr
}

\begin{abstract}
This article examines cost accounting methods containing one or more activity-based costing (ABC) like dimensions. The objective is to analyze cost accounting proposals with, in part, a philosophy reminiscent $\mathrm{ABC}$. The research purposes are to analyze the strategic dimension of the methods described and to build a typology useful for managers. The discussion leads to a four-dimensional typology based on three strategic objectives assigned to the cost accounting systems. The foundation of the research is the Strategic Cost Management Theory from which emerges the ABC philosophy. The methodology applied is an academic and professional literature review. The typology designed shows common points and similarities of the methods observed and their strategic dimensions. Some of the methods studied are more or less useful for practitioners, according to the situation of their companies.
\end{abstract}

Keywords: strategic cost management, activity-based costing, typology

$\underline{\text { ARTICLE INFO }}$

\section{Article History:}

Received: 28 February 2019

Accepted: 23 July 2019

Published: 31 August 2019 


\section{INTRODUCTION}

The conventional approach to management accounting (Anthony, 1993) reveals a conflict among the processes of strategic management, management control and operational control. Johnson and Kaplan (1987) explain that coordination between these processes is difficult to achieve. The strategic management accounting theory is a concept and a set of practices devised to overcome this difficulty.

There has been a growing interest in strategic management accounting since the early 1980s (Simmonds, 1981). In a firm, a strategic management accounting instrument connects strategic and marketing decisions with operational ones and brings a multi-dimensional approach of performance (Mike \& Yi, 2009). For instance, Simmonds (1981) and Bromwich (1990) suggest using qualitative and external measures with three dimensions of analysis: products and customers (e.g. their level of satisfaction), competition (level of penetration), and the environment. Scholars have studied the strategic management accounting concept in depth over time (Wilson, 1995). More recently, Smith (2017) reflects on the concept in a new way, linking it to the integrated reporting framework.

Strategic cost management is one dimension of strategic management accounting dedicated to cost management in relation to strategy. Several scholars have been promoting the benefits of strategic cost management (Shank \& Govindarajan, 1989, 1994; Wong, 1996; Freeman, 1998; Cooper \& Slagmulder, 1998, 2003; Anderson, 2007).

Three ways to approach strategic cost management are considered:

1. A restrictive way. Cost management scans the range of strategic options and control the strategic hypotheses. It is an ex post approach.

2. An intermediate way. Cost management validates the strategic hypotheses. It is a more dynamic approach that requires a more detailed analysis of strategic assumptions. They are key success drivers that cost management sets up along the company's value chain. Shank and Govindarajan $(1989 ; 1992)$ explain that the key value drivers are cost drivers that $\mathrm{ABC}$ is able to highlight. 
3. A broad approach where costing is a fundamental part of the strategy. With this approach, cost management should be interactive (see the concept of interactive control developed by Simons, 1995). According to strategic situations and environmental uncertainties, managers choose relevant cost management instruments to become interactive, using them to articulate the strategic and operational processes and to identify new strategic opportunities.

Intermediate and broad strategic cost management imply more participation of employees. They require a knowledge-based approach to management as developed by Argyris and Schön (1978) through the organizational learning theory. In this context, value creation is the result of an increase in resources (resource-based view approach, Penrose, 1959) and competencies (core-competencies theory, Hamel \& Prahalad, 1990). In this way, in order to be an efficient strategic decision-making tool, a strategic cost management system must closely follow each step in the implementation of strategy and the achievement of pre-defined objectives.

If Tomkins and Carr (1996) explain that "there is still no agreed comprehensive conceptual framework for what strategic management accounting" and Sha, Malik and Malik (2011) that "empirical evidences so far are not very strong to lead us to a convincing belief that strategic management accounting will deliver all that it promises today", Hoffjan and Wömpener (2006) point out that several strategically oriented cost management tools are well developed in firms such as: customers profitability cost management, target costing and ABC. Fu (2007) applies the concept of strategic cost management to E-supply chain. Cinquini and Tenucci (2010) present the results of an empirical study about medium-sized Italian firms. Most of them use strategic cost management instruments.

Is the $\mathrm{ABC}$ method able to drive each step of the strategy and to control the achievement of strategic goals? Is it also able to validate the strategic hypotheses and to engender new strategies? This article first demonstrates that $\mathrm{ABC}$ is a strategic cost management instrument. 


\section{THE ACTIVITY-BASED COSTING METHOD, A WAY TO DRIVE STRATEGICALLY THE COSTS}

This section demonstrates that strategic cost management is the theoretical base of $\mathrm{ABC}$. First, a brief reminder of what $\mathrm{ABC}$ represents is proposed.

Several scholars and practitioners designed the $\mathrm{ABC}$ method during the 1980s (Berliner \& Brimson, 1988; Cooper \& Kaplan, 1988). ABC emerged in an increasingly complex environment leading to higher overhead costs. $\mathrm{ABC}$ is a refined cost system enabling first to classify more costs as direct, second to expand the number of indirect-cost pools and third to identify cost drivers. $\mathrm{ABC}$ favors better cost allocations using smaller cost pools called activities.

A sophisticated cost assignment approach, which assigns resources to activities and then costs to costs objects, is at the heart of the method. Using cost drivers, the costs of the activities are the basis for assigning costs to cost objects such as products or services. Since the seminal work of Johnson and Kaplan (1987) on the "Relevance Lost" of management accounting practices, several management accounting developments based on the strategic management accounting stream emerged. The historical research of Johnson and Kaplan helps to understand the context from which ABC arose. Looking for management accounting methods which could clarify the decision making process, they first suggest a more in-depth analysis of the activities and processes and, second, a closer link between strategic and operational management. These proposals prefigure the development of the balanced scorecard (Kaplan \& Norton, 1996) and a strategy-oriented ABC.

The structure of $\mathrm{ABC}$ makes it possible to understand its natural strategic orientation: the central role of the cost driver concept as a variable which explains costs consumption and describes value chains materializes the link between strategic and operational management. A process approach is at the heart of $\mathrm{ABC}$ and the company is seen as a network of horizontal, flat, and transverse structures where the activities depend on market requirements.

To correct misleading overhead allocations was the first objective when designing $\mathrm{ABC}$. It was a response to the inaccurate American 
standard costing methods. However, several academics, like Lebas (1999) in France, explain that $\mathrm{ABC}$ rapidly gained managerial (activity-based management) and strategic dimensions. Jones and Dugdale (2002) point out the links between $\mathrm{ABC}$ and the strategic cost management theory. Shank and Govindarajan (1989) developed an operational model with the definition of key success factors, determined using a competitive analysis of the environment and an analysis of the internal processes, with the help of $\mathrm{ABC}$. This $\mathrm{ABC}$ is a strategic cost management system with a life cycle and value chain perspective. Using the works of Porter (1985), Shank et Govindarajan suggest integrating the customer and supplier dimensions within the cost allocation system.

To synthesize, $\mathrm{ABC}$ makes it possible to decipher organizational architecture, the links between strategic and operational management, to question strategic hypotheses and lighting new ones. An historical background shows that firms have experimented several cost management tools based on $\mathrm{ABC}$. The next section presents the diversity of costing methods based on $\mathrm{ABC}$.

\section{A GREAT DIVERSITY OF COST ACCOUNTING METHODS BASED ON ABC}

This section presents developments observed during the last twenty years. The section focuses on the most diffused technics. The next section completes the list.

First, academic and professional literatures put a strong emphasis on $\mathrm{ABC}$ developments taking into account stakeholders (stakeholder theory, Freeman, 1984) as costs objects and more especially the customers. Through a customer profitability analysis (Horngren, Foster, Datar, Rajan \& Ittner, 2005) using an activity-based approach, the managers try to optimize the customers' relations processes. The literature offers numerous developments on the customer dimension of cost management. Otley (2003) reviews the evolution of management accounting. He describes the fact that the notion was originally associated to economic rationality, internal control and a shareholder view. He explains that later on, due to a changing environment, the attention shifted from internal control to value chain management. This 
evolution reflects the need to coordinate internal and external processes. Other contributions also focus on expanding cost management to customer analysis: Brignall and Ballantine (1996), Ballantine, Brignall and Model (1998), Ittner, Larcker and Randall (2003) and Cugini Caru, and Zerbini (2007). ABC is particularly suited to a customer perspective. Value chain analysis and cost drivers, at the heart of $\mathrm{ABC}$, emphasize the role of customer relations in value creation.

Second, companies can use $\mathrm{ABC}$ to obtain more accurate future costs and budgets. Horvath, Gleich and Schmidt (1998), Antos and Brimson (1999), Cokins (2002) and CAM-I studies (Consortium for Advanced Management International ${ }^{1}$ ) have developed the activity-based budgeting and activity-based planning and budgeting models.

Third, taking into account critics about ABC (Datar \& Gupta, 1994; Malmi, 1997), Keys and van der Merwe (2002a, 2002b) develop the resource consumption accounting (RCA) method, looking for a refinement of $\mathrm{ABC}$ at the resource allocation process level. The RCA method adds another allocation phase from the resources to pools and systematically distinguish variable from fixed costs. The RCA method proposes a more refined task architecture, a more rationalized allocation process of resources to activities and statistical approaches to correlate the consumption of resources and activities with the cost drivers.

Fourth, by contrast, experts have developed a simplified ABC that can be suitable for simplified and/or intangible processes, as part of service activities for instance. The activity can be an excessive level of detail in sectors with a lot of intangible processes. When the process complexity is low or intangible, a simplified $\mathrm{ABC}$ is adapted, combining several activities into one meta-activity or into a process with a single cost driver. The timedriven ABC (TDABC, Kaplan \& Anderson, 2007) is the most famous method of that kind.

As mentioned at the beginning of the section, the list is not exhaustive but makes it possible to highlight certain characteristics conducting to a global typology presented in the next section.

$1 \quad$ See http://www.cam-i.org/ 


\section{PROPOSAL FOR A TYPOLOGY}

The proposed typology is the outcome of an academic and professional reading review. Developments in the following section after Table 1 details several of the practices observed.

The literature review highlights three strategic objectives in relation to the developments observed:

1. Diversifying the cost objects (not only to products but also to customers, services, processes, suppliers, environment, etc.),

2. Broadening the scope of cost analysis (spatial and temporal extension),

3. Determining the relevant level of cost analysis complexity: refinement or simplification of cost calculations.

These three objectives converge towards a single one: to provide strategic direction for cost calculations in accordance with the Strategic Cost Management Theory. These objectives fall into the four perspectives of the typology. Figure 1 shows the links between the objectives and the perspectives. A first observation is that an objective can be associated with several categories. For example, a simplified ABC (relevant level of cost analysis) can conduct to analyze customers' profitability (cost objects diversification) and/or future costs (cost scope broadening). 
Shared

objective divided into three objectives
Four perspectives identified

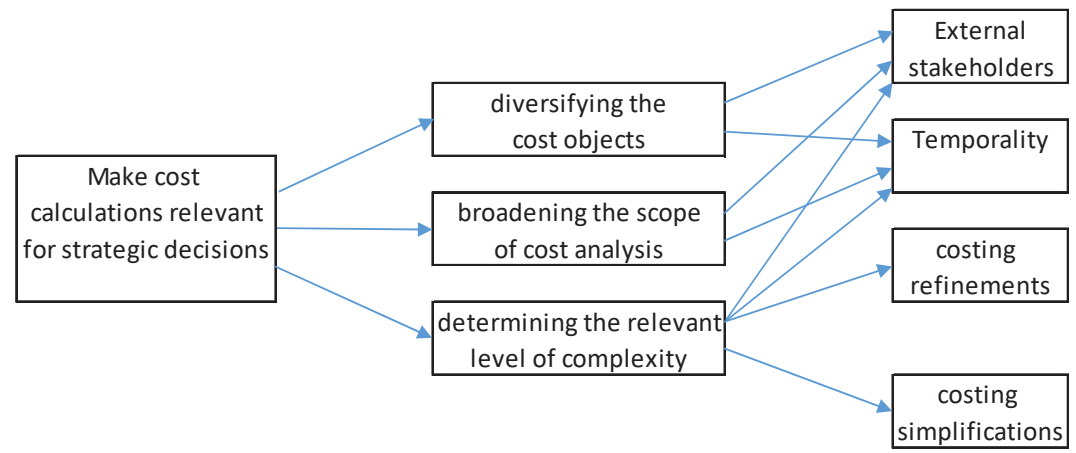

Figure 1: Links between Cost Accounting Objectives and Typology Perspectives

Table 1 presents the four perspectives and gives some details about the practices observed.

Table 1: Four Typology Perspectives and Cost Accounting Practices Identified

\section{Perspectives \\ Practices identified}

\section{1st perspective: External stakeholders}

Feature: trends towards extending the scope of cost analysis to external stakeholders

Extension to customers, suppliers, partners, environment and other stakeholders
$A B C \&$ customer-driven cost accounting

$A B C$ \& supplier-driven cost accounting $A B C$ \& environmental cost accounting

Interorganizational cost management

\section{2nd perspective: Temporality}

Feature: costing methods focused on $A B C$ \& strategic planning, long-term programming

future costs to facilitate forwardActivity-based budgeting, Activity-based looking \& life-cycle analyses planning Beyond budgeting $A B C$ \& life-cycle costing $A B C$ \& project cost accounting $A B C$ \& target-costing 


\section{Perspectives}

Practices identified

\section{3rd perspective: Costing refinements}

Feature: cost accounting with analytical refinements

Refinement of the resource allocation stage

Diversification of cost drivers

Mathematical approaches
$A B C$ \& resource consumption accounting

$A B C$ \& feature costing

multivariate drivers, costs modularization

mathematical programming

\section{4th perspective: Costing simplifications}

Feature: Cost accounting with Simplified ABC

simplifications

Depending on the context and type of Time-driven ABC company:

Simplification of the resource allocation stage

Reduction of activities \& number of costs drivers

Cost accounting methods focused on processes

Table 1 distinguishes four perspectives. A cost accounting system can use one or several of the perspectives described.

1. The first perspective focuses on external stakeholders. Taking into account external stakeholders in its cost accounting systems, a company can experience a positive impact on its decision making process.

2. The second perspective focuses on future-cost oriented methods to contribute to the prospective and life-cycle analyses.

3. The third perspective regroups attempts to refine costing systems on different aspects: resource allocation, cost drivers diversification and mathematical refinements.

4. The fourth perspective regroups attempts to simplify costing systems. 


\section{ANALYSIS OF OBSERVED PRACTICES IN LIGHT OF THE FOUR PERSPECTIVES AND CASE STUDY}

Based on the previous developments, this part analyzes the content of the typology in more detail.

\section{Detailed Analysis of the Four Perspectives}

Since its beginning, $\mathrm{ABC}$ has also been approached from a managerial perspective. The $\mathrm{ABC}$ methodology, which is highly analytical, also seemed more suitable for modelling industrial costs. It seems to be easier to break down industrial processes into activities and cost drivers are easier to express in physical values: labor and engine hours, number of batches, volume of production orders, numbers of fabrication orders, volume of setting minutes, etc. However, value creation also results from what happens outside the company, through the customer and supplier relations and from service activities.

\section{First Perspective: External Stakeholders}

Since its early stages, researchers point out the usefulness of $A B C$ to take into account the value of customers (Lebas, 1999).

The principle of customer profitability analysis mixed with $\mathrm{ABC}$, is to reorganize the costing architecture to focus on customers, markets or other commercial and marketing aspects as cost objects. Kuchta and Troska (2007) explain that $\mathrm{ABC}$ is a good method for profiling customer profitability. They believe that a customer-driven $\mathrm{ABC}$ “....can help determine which products and customers are the most profitable, which activities are customer-focused, whether processes are customer value-added or not, and where efforts toward customer-related improvements should be made".

Several researches analyze other external stakeholders. This is the case with environmental costs through an $\mathrm{ABC}$ methodology. Tsai, Chena, Liub, Chen and Shen (2011) use ABC to assess the performances and benefits generated by the adoption of green manufacturing systems. In another study, Tsai and Hung (2009) integrate ABC into a value-chain to optimize supplier selection to obtain a green supply chain. 
With an extension of the scope of cost analysis to customers, suppliers, partners and environment, $\mathrm{ABC}$ focuses on optimizing the company's external performance. Cooper and Slagmulder (2004) describe a methodology they call "interorganizational cost management (IOCM)" that comes from observing Japanese practices (see also Agndal \& Nilsson, 2009; Fayard, Lee, Leitch \& Kettinger, 2012). Researchers have also reported studies elsewhere than in Japan. Chiarini and Vagnoni (2015) show, with the example of the Italian company Fiat, that $\mathrm{ABC}$ combined with an IOCM process can be useful for calculating wastes and losses in the production process. Sohn, Shin and Park (2015) describe an IOCM system in a Korean distribution company, Hofmann and Bosshard (2017) the ways in which $\mathrm{ABC}$ can be used to manage the supply chain.

From an IOCM perspective, cost calculations include at least two firms. $\mathrm{ABC}$ facilitates the description of the value chain between them. With target costing, the leading company in the value chain identifies an estimated price that customers are willing to pay and then, with the supplier part of the value chain, a target cost to achieve the expected profit is determined. One important question is what costs should be included in the target calculations. Cost reduction efforts often need to be extended to all levels of the value chain, from research and development to customer service, including the search for the lowest prices for materials and components. $\mathrm{ABC}$ helps determine which activities and costs fall into value-added or non-value-added categories. It also identifies costs along the value chain and analyses the effects of a change in product design on costs. Cooper and Slagmulder (2004) call this process the "costs interorganizational investigation". With an IOCM process, the relevant costs are future costs because target costing promotes long-term analyses, considering the life cycle of a project. in this context, IOCM practice can also refer to the second perspective of the typology.

\section{Second Perspective: Temporality}

Concerning the second perspective of the typology, the strategic dimension is quite obvious. The common objective of cost accounting systems from this perspective is to analyze future costs. The practices described here seek to extend the temporal scope of cost analysis. This is the case with activity-based budgeting (Antos \& Brimson, 1999; Hansen, 
2011), activity-based planning and budgeting (Sandison, Hansen \& Torok, 2003) and beyond budgeting (Bourmistrov \& Kaarboe, 2013) ${ }^{2}$. Through a questionnaire conducted in oil companies that implement $\mathrm{ABC}$ and activitybased planning in Yemen, Dhubea and Al-Riami (2018) show that activitybased planning has a positive influence on the decision making process.

Horvath et al. (1998) combine target costing and ABC at a US automotive supplier and Tsai et al. (2015) life-cycle costing and ABC for green-decision making. Knauer and Möslang (2018) analyze the adoption and benefits of life-cycle costing through questionnaires collected from a survey of German firms. They show that the greatest benefit of life-cycle costing is related to the identification of cost drivers.

The managerial dimension is also present in the proposals described here. A point to highlight concerning activity-based budgeting, activitybased planning and budgeting, beyond budgeting, target costing and life cycle costing is that, at some point in the process of these methods, a logic specific to the $\mathrm{ABC}$ method is deployed. One of the most interesting aspects is the central role of cost drivers which become cost triggers in this forward-looking perspective, tracking accurate future costs thanks to a refined assignment process.

\section{Third Perspective: Towards Costing Refinements}

The third and fourth perspectives of the typology group together methods to find the relevant level of granularity to analyze costs, according to the strategic and organizational specificities of the company. In some cases, the level of complexity is significant. A method such as "resource consumption accounting (RCA, see Clinton \& van der Merwe, 2008; AlHebry, 2017) completes ABC with a more in-depth analysis of resources. Within complex processes, the variety of resources is important, which requires a large number of resource drivers and more complex allocation processes. With RCA, resources are classified in pools, which makes it easier to assign them to activities. RCA tries to improve the allocation process so that managers have a clearer vision of the consequences of their strategic decisions. RCA systems provide decision-makers with more detailed information than $\mathrm{ABC}$.

2 Activity-based planning and budgeting and beyond budgeting have been promoted by CAM-I (Consortium for Advanced Management International: http://www.cam-i.org) 
RCA adds a distinction between variable and fixed costs, making shortterm marginal calculations possible. One or more driver can be deployed per pool, resources are assessed on a quantitative basis and there are more cost centers. RCA has a lot in common with $\mathrm{ABC}$ : they both use a value chain analysis, charge manufacturing and non-manufacturing costs to cost objects using cost drivers and exclude non-traceable costs. They both use cost drivers that can be volume and non-volume related. RCA has also several differences with $\mathrm{ABC}$. $\mathrm{ABC}$ focuses on activities whereas RCA mainly on resources. $\mathrm{ABC}$ does not distinguish between fixed and variable costs, the costs of capacity are not measured, historical cost depreciations are favored and financial reporting feed the cost system. Differently, with RCA, the fixed and variable costs are separated, managers keep an eye on cost centers, the measure of unused capacities by cost center is easy, replacement cost depreciations are favored and the cost system and financial reporting are integrated. The major advantage of RCA is that it makes it possible to combine strategic analyses with shorter-term ones. But the main difficulties with RCA are that it is time consuming and difficult to implement. It requires investment in a powerful enterprise resource planning.

Feature costing (Brimson, 1998; Cokins, 2002; Filomena et al., 2011) introduces a new level of analysis to $\mathrm{ABC}$ : the features of a product. With this general idea, a cost accounting system can complement $\mathrm{ABC}$ with characteristics relating to the industrial process of a product, a service or a category of customers. Researchers propose other types of refinements such as Park and Simpson (2008), with cost modularization (costs map to individual parts in the product family), or Bazrafshan and Karamshahi (2017) with multivariate drivers, pools categories and costs behavioral modelling. Other proposals tend to refine $\mathrm{ABC}$ with mathematical programming at different levels such as Khataie, Defersha and Bulgak (2010) for the supplychain level, Tsai et al. (2015) for life-cycle and environment costs or Zhuang and Chang (2017) who combine TDABC and programming modeling. Balakrishnan, Labro and Sivaramakrishnan (2012a, 2012b) develop a conceptual framework to compare classic product costing, ABC, RCA and TDABC which is the subject of the following section. 


\section{Fourth Perspective: Towards Simplifications}

In other situations, the process is less complex so that standard $\mathrm{ABC}$ is oversized or unsuitable. Solutions to simplify ABC then emerge such as:

1. Process cost accounting (Horngren et al., 2005),

2. Lean accounting (Maskell, Bagaley \& Grasso, 2003),

3. Value-stream costing (Abuthakeer, Mohanram \& Kumar, 2010).

Time-driven ABC (TDABC, Kaplan \& Anderson, 2007) is the most renowned method to simplify $\mathrm{ABC}$. TDABC is classified in the category of equivalence costing methods. With this technique, the division into activities can be simpler (as with process costing and lean accounting approaches). The principle of TDABC is to translate cost drivers into time equivalents (in standard of working hours). Changes in production conditions lead to a revision of standards. TDABC is a way to introduce standard costs in an $\mathrm{ABC}$ model

Here is an example of a sales department with three activities: order processing, client complaints and invoice payment. Instead of cutting the department into three distinct activities and allocating their costs with relevant drivers, a time equation based on standards is defined such that:

$$
\mathrm{T}=8 \times \mathrm{X} 1+44 \times \mathrm{X} 2+2 \times \mathrm{X} 3
$$

With:

$\mathrm{X} 1=$ number of orders to process,

$\mathrm{X} 2$ = number of complaints,

$\mathrm{X} 3$ = number of invoices.

The literature offers a wide variety of TDABC case studies. Santana and Afonso (2014) analyze twenty studies published in the ISI database showing that TDABC has been implemented in different countries and sectors such as distribution (Everaert, Bruggeman, Sarens, Anderson \& Levant, 2008), manufacturing companies (Oker \& Adigüzel, 2010), hospitality business (Dalci, Tanis \& Kosan, 2010) and health care organizations (Balakrishnan, 
Pugely \& Shah, 2017; Keel, Savage, Rafiq \& Mazzocato, 2017). TDABC is based on a strong assumption: working time consumption correlates with cost generation. This is the case in certain circumstances, notably when processes and services are standardized, such as for supply chains, hospital activities or bookstores. This is why Hoozée Vermeire and Bruggeman (2012) explain that firms using TDABC would benefit from using transaction-level data to test the relevance of time-drivers. Hoozée and Hansen (2018) clarify the differences between ABC and TDABC and explain in which situations which method is more accurate. They also test melding the two systems and outline interesting perspectives for improving cost calculation systems.

\section{DISCUSSION AND CONCLUSION}

The article examined strategic cost management with a focus on cost accounting methods in relation to $\mathrm{ABC}$. The developments show that $\mathrm{ABC}$ is a strategic cost management instrument: it helps driving each step of the strategy, controlling the achievement of strategic goals, validating the strategic hypotheses and engender new strategies. The central role of cost drivers, the process and cross-functional approaches are fundamental to understanding this strategic dimension.

The research highlights three major objectives of $\mathrm{ABC}$ : diversifying the cost objects, broadening the scope of cost analysis and determining the relevant level of cost analysis complexity. These three objectives are embodied in a typology of $\mathrm{ABC}$ profiles in four categories: external stakeholders, temporality, costing refinements, costing simplifications. This research shows the great diversity of possible applications with $\mathrm{ABC}$ and therefore the richness of the method, beyond its intrinsic limits.

Several proposals emerge from the research:

1. Proposal 1 - A stakeholder-oriented ABC (first perspective of the typology) is of particular interest to researchers and professionals for different reasons: the strategic dimension of the method encourages to broaden its scope of analysis, the development of work on management accounting in service activities, customer and supplier as key cost 
objects and interest in new cost object types. $\mathrm{ABC}$ and environmental cost accounting and interorganizational cost management taking Japanese practices as a reference are very stimulating proposals.

2. Proposal 2 - A simplified ABC with a limited number of drivers, activities grouped into meta-activities and the use of simplified processes is a strong trend. Time-driven ABC is a good illustration of this trend. In service activities and in processes where the IT business is a key driver, a limited number of processes modelled from the consumption of working time and computer instructions is relevant. This evolution can also be associated with the lean accounting movement and may lead to questions about the future of ABC. Are the simplified cost accounting methods not ultimately a renunciation of the initial project carried out by $\mathrm{ABC}$ ?

3. Proposal 3 - Even if complex ABC models exist, the latter do not seem to arouse as much interest as the two trends mentioned above. Further investigation should also confirm or deny this proposal. It may be that recent developments around big data and artificial intelligence can lead to the emergence of more complex and user-friendly costing models.

4. Proposal 4 - Similarly, the number of studies on the use of ABC for prospective analyses seems to be of limited interest. Here again, an investigation approach will allow to examine this question in greater depth. Trends towards simplifying budgetary processes, the use of rolling forecasts and non-financial indicators may raise doubts about the value of $\mathrm{ABC}$ in this area.

5. Proposal 5 -A last point concerns the elasticity of the method. The work shows that $\mathrm{ABC}$ is easily malleable and allows to combine several of the indicated dimensions. For instance, a customer-driven $\mathrm{ABC}$ can be combined with a simplified version of the method. In addition, the $\mathrm{ABC}$ method appears to be a complement to cost accounting systems that can be adjusted according to the objectives sought. The timedriven $\mathrm{ABC}$ can complete a full or partial cost management system by using time drivers for customer relationship analysis. This elasticity also leads to a risk of dilution of $\mathrm{ABC}$ and a questioning of the very 
principles of the method. For example, a simplified version of $\mathrm{ABC}$ may seem contradictory to the principle of searching for finer cost analysis meshes, and the time-driven $\mathrm{ABC}$ contradictory with the search for a diversity of cost drivers and real costs.

Future research, through case studies and questionnaires, will be able to compare the proposals made with real situations.

\section{REFERENCES}

Abuthakeer, S. S., Mohanram, P. V., \& Kumar, G. M. (2010). Activity based costing value stream mapping. International Journal of Lean Thinking, 1(2), 51-64.

Agndal, H., \& Nilsson., U. (2009). Interorganizational cost management in the exchange process. Management Accounting Research, 20, 85-101.

Al-Hebry, A. A. (2017). Proposed framework to determine appropriateness of cost accounting methods. Cost Management, March/April, 6-15.

Anderson, S. W. (2007). Managing costs and cost structure throughout the value chain: Research on strategic cost management. In C. S. Chapman, A. G. Hopwood \& M. D. Shields (Eds.), Handbook of management accounting research. Oxford, UK: Elsevier.

Anthony, R. N. (1993). La fonction contrôle de gestion [The Management Accounting Function]. Paris: Publi-Union.

Antos, J., \& Brimson. J. A. (1999). Driving value using activity-based budgeting. New-York: John Wiley \& Sons.

Argyris, C., \& Schön. D. A. (1978). Organizational Learning. Readings, MA: Addison-Wesley Publishing Company.

Balakrishnan, R., Labro, E., \& Sivaramakrishnan, K. (2012a). Product costs as decision aids: An analysis of alternative approaches (Part 1). Accounting Horizons, 26(1), 1-20. 
Balakrishnan, R., Labro, E., \& Sivaramakrishnan, K. (2012b). Product costs as decision aids: An analysis of alternative approaches (Part 2). Accounting Horizons, 26(1), 21-41.

Balakrishnan, R., Pugely, A. J., \& Shah, A. S. (2017). Modeling resource use with time equations: Empirical evidence. Journal of Management Accounting Research, 29(1), 1-12.

Ballantine, J., Brignall, S., \& Model, S. (1998). Performance measurement and management in public health services: A comparison of U.K. and Swedish practice. Management Accounting Research, 9, 71-94.

Bazrafshan, S., \& Karamshahi, B. (2017). Examining the disadvantages of activity based costing (ABC) system and introducing the modern (Behavior Based Costing) (BBC) system. International Journal of Management, Accounting and Economics, 4(2), 163-177.

Berliner, C., \& Brimson, J.A. (1988). Cost management in today's advanced manufacturing environment: The CAM-I conceptual design. Boston, MA: Harvard Business School Press.

Bourmistrov, A., \& Kaarboe, K. (2013). From comfort to stretch zones: A field study of two multinational companies applying "beyond budgeting" ideas. Management Accounting Research, 24, 196-211.

Brignall, S., \& Ballantine, J. (1996). Performance measurement in service businesses revisited. International Journal of Service Industry Management, 7(1), 6-31,

Brimson, J. A. (1998). Feature costing: Beyond ABC. Journal of Cost Management, January-February, 6-12.

Bromwich, M. (1990). The case for strategic management accounting: The role of accounting information for strategy in competitive markets. Accounting Organizations and Society, 15(1-2), 127-146.

Chiarini, A., \& Vagnoni, E. (2015). World-class manufacturing by Fiat. Comparison with Toyota production system from a strategic 
management, management accounting, operations management and performance measurement dimension. International Journal of Production Research, 53(2), 590-606.

Cinquini, L., \& Tenucci, A. (2010). Strategic management accounting and business strategy: A loose coupling? Journal of Accounting and Organizational Change, 6(2), 228-259.

Clinton, B. D., \& van der Merwe, A. (2008). Understanding resource consumption and cost behavior - Part II. Cost Management, 22(4), $14-20$.

Cokins, G. (2002). Integrating target costing and ABC. Journal of Cost Management, July-August, 13-22.

Cooper, R., \& Kaplan, R. S. (1988). Measure costs right: Make the right decisions. Harvard Business Review, September-October, 96-103.

Cooper, R., \& Slagmulder, R. (1998). Strategic cost management: What is strategic cost management? Management Accounting, 79(7), 14-16.

Cooper, R., \& Slagmulder, R. (2003). Strategic cost management: Expanding scope and boundaries. Journal of Cost Management, 17, 23-30.

Cooper, R., \& Slagmulder, R. (2004). Interorganizational cost management and relational context. Accounting Organization and Society, 29, 1-26.

Cugini, A., Caru, A., \& Zerbini, F. (2007). The cost of customer satisfaction: A framework for strategic cost management in service industries. European Accounting Review, 16(3), 499-530.

Dalci I., Tanis, V., \& Kosan, L. (2010). Customer profitability analysis with time-driven activity-based costing: A case study in a hotel. International Journal of Contemporary Hospitality Management, 22(5), 609-637.

Datar, S., \& Gupta, M. (1994). Aggregation, specification and measurement errors in product costing. The Accounting Review, 69(4), 567-591. 
Dhubea, H. M. S. B., \& Al-Riami, S. A. (2018). The application of activitybased costing and activity-based planning influences decision making. Asia-Pacific Management Accounting Journal, 12(1), 1-38.

Everaert, P., Bruggeman, W., Sarens, G., Anderson, S. R., \& Levant, Y. (2008). Cost modeling in logistics using time-driven ABC: Experiences from a wholesaler. International Journal of Physical Distribution \& Logistics Management, 38(3), 172-191.

Fayard, D., Lee, L. S., Leitch, R. A., \& Kettinger, W. J. (2012). Effect of internal cost management, information systems integration, and absorptive capacity on inter-organizational cost management in supply chains. Accounting, Organizations and Society, 37(3), 168-187.

Filomena, T. P., Anzanello, M. J., Neto, F. J. K., Duffey, M. R., \& CamposNáñez, E. (2011). Manufacturing feature-based cost management system: A case study in Brazil. Production Planning \& Control, 22(4), 414-425.

Freeman, R. E. (1984). Strategic management: A stakeholder approach. Boston: Pitman.

Freeman, T. (1998). Transforming cost management into a strategic weapon. Journal of Cost Management, 12, 13-26.

Fu, Y. (2007). Strategic cost management in e-supply chain. Asia-Pacific Management Accounting Journal, 2(1), 89-119.

Hamel, G., \& Prahalad, C. K. (1990). The core competence of the corporation. Harvard Business Review, 68(3), 79-92.

Hansen, S. C. (2011). A theoretical analysis of the impact of adopting rolling budgets, activity-based budgeting, and beyond budgeting. European Accounting Review, 20(2), 289-319.

Hoffjan, A., \& Wömpener, A. (2006). Comparative analysis of strategic management accounting in German - and English - language general management accounting textbooks. Schmalenbach Business Review, $58,234-258$. 
Hofmann, E., \& Bosshard, J. (2017). Supply chain management and activitybased costing: Current status and directions for the future. International Journal of Physical Distribution \& Logistics Management, 47(8), 712-735.

Hoozé, S., \& Hansen, S. C. (2018). A comparison of activity-based costing and time-driven activity-based costing. Journal of Management Accounting Research, 30(1), 143-167.

Hoozée, S., Vermeire, L., \& Bruggeman, W. (2012). The impact of refinement on the accuracy of time-driven ABC. Abacus, 48(4), 439-472.

Horngren, C. T., Foster, G., Datar, S. M., Rajan, M. V., \& Ittner, C. M. (2005). Cost accounting - A managerial emphasis (12th ed.). Upper Saddle River, New Jersey: Pearson Education.

Horvath P., Gleich, R., \& Schmidt, S. (1998). Linking target costing to ABC at a US automotive supplier. Journal of Cost Management, 12(2), 16-24.

Ittner, C. D., Larcker, D. F., \& Randall, T. (2003). Performance implications of strategic performance measurement in financial services firms. Accounting, Organizations and Society, 28(7-8), 715-741.

Johnson, H. T., \& Kaplan, R. S. (1987). Relevance lost: The rise and fall of management accounting systems. Boston: Harvard Business School Press.

Jones, T. C., \& Dugdale, D. (2002). The ABC bandwagon and the juggernaut of modernity. Accounting Organizations and Society, 27, 121-163.

Kaplan, R. S., \& Anderson, S. R. (2007). Time-driven activity-based costing. Boston: Harvard Business School Press.

Kaplan, R. S., \& Norton, D. P. (1996). The balanced scorecard - Translating strategy into action. Boston: Harvard Business School Press.

Keel, G., Savage, C., Rafiq, M., \& Mazzocato, P. (2017). Time-driven activity-based costing in health care: A systematic review of the literature. Health Policy, 121, 755-763. 
Keys, D. E., \& van der Merwe, A. (2002a). The case for resource consumption accounting. Strategic Finance, 83(10), 30-36.

Keys, D. E., \& van der Merwe, A. (2002b). The case for resource consumption accounting. Strategic Finance, 83(11), 41-47.

Khataie, A., Defersha, F. M., \& Bulgak, A. A. (2010). Multi-objective optimisation approach for order management: Incorporating activitybased costing in supply chains. International Journal of Production Research, 48(17), 5007-5020.

Knauer, T., \& Möslang, K. (2018). The adoption and benefits of life cycle costing. Journal of Accounting \& Organizational Change, 14(2), 188215 .

Kuchta, D., \& Troska, M. (2007). Activity-based costing and customer profitability. Cost Management, 21(3), 18-25.

Lebas, M. (1999). Why ABC? Accounting based on causality rather than activity-based costing. European Management Journal, 17(5), 501-511.

Malmi, T. (1997). Towards explaining activity-based costing failure: Accounting and control in a decentralised organization. Management Accounting Research, 8, 459-480.

Maskell, B. H., Bagaley, B., \& Grasso, L. (2003). Practical lean accounting: A proven system for measuring and managing the lean enterprise. New York: Productivity Press.

Oker, F., \& Adigüzel, H. (2010). Time-driven activity-based costing: An implementation in a manufacturing company. The Journal of Corporate Accounting \& Finance, 22(1), 75-92.

Otley, D. T. (2003). Management control and performance management: whence and whither? British Accounting Review, 35(4), 309-326.

Park, J., \& Simpson, T. W. (2008). Toward an activity-based costing system for product families and product platforms in the early stages 
of development. International Journal of Production Research, 46(1), 99-130.

Penrose, E. (1959). The theory of the growth of the firm. Oxford, UK: Oxford University Press.

Porter, M. (1985). Competitive advantage: Creating and sustaining superior advantage. New York: The Free Press.

Sandison, D., Hansen, S. C., \& Torok, R. G. (2003). Activity-based planning and budgeting: A new approach. Journal of Cost Management, March/ April, 16-22.

Santana, A., \& Afonso, P. (2014). Analysis of studies on time-driven activitybased costing (TDABC). The International Journal of Management Science and Information Technology (IJMSIT), 133-157.

Sha, H., Malik, A., \& Malik, M. S. (2011). Strategic management accounting - A messiah for management accounting? Australian Journal for Business and Management Research, 1(4), 1-7.

Shank, J. K., \& Govindarajan, V. (1992). Strategic cost management: The value chain perspective. Journal of Management Accounting Research, 4, 179-197.

Shank, J. K., \& Govindarajan, V. (1994). Strategic cost management. New York, NY: The Free Press.

Shank, J., \& Govindarajan, V. (1989). Strategic cost analysis: The evolution from managerial to strategic accounting. Homewood, IL: Irwin.

Simmonds, K. (1981). Strategic management accounting. Management Accounting, 59(4), 26-29.

Simons, R. L. (1995). Levers of Control. Boston: Harvard Business School Press. 
Smith, S. T. (2017). Strategic management accounting. delivering value in a changing business environment through integrated reporting. New York: Business Expert Press.

Sohn, S. K., Shin, I. H., \& Park, S. (2015). Implementation of interorganizational cost management and its infrastructure: The case of a Korean 'Chaebol' firm. Asia Pacific Business Review, 21(2), 228-250.

Tomkins, C., \& Carr, C. (Eds). (1996). Special Issue on Strategic Management Accounting. Management Accounting Research, 7, 165-167.

Tsai, W. H., \& Hung, S. J. (2009). A fuzzy goal programming approach for green supply chain optimisation under activity-based costing and performance evaluation with a value-chain structure. International Journal of Production Research, 47(18), 4991-5017.

Tsai, W. H., Chena, H. C., Liub, J. Y., Chen, S. P., \& Shen, Y. S. (2011). Using activity-based costing to evaluate capital investments for green manufacturing systems. International Journal of Production Research, 49(24), 7275-7292.

Tsai, W. H., Tsaur, T. S., Chou, Y. W., Liu, J. Y., Hsu, J. L., \& Hsieh, C. L. (2015). Integrating the activity-based costing system and life-cycle assessment into green decision-making. International Journal of Production Research, 53(2), 451-465.

Wilson, R. M. (1995). Strategic Management Accounting. In Issues in Management Accounting, edited by D. Ashton et al. New York: Prentice Hall, 2nd ed.

Wong, M. (1996). Strategic cost management. Management Accounting, 74(4), 30 .

Zhuang, Z. Y., \& Chang, S. C. (2017). Deciding product mix based on timedriven activity-based costing by mixed integer programming. Journal of Intelligent Manufacturing, 28, 959-974. 